\title{
The hieratic dockets on the cuneiform tablets from Amarna
}

Hagen, Frederik Norland

Published in:

Journal of Egyptian Archaeology

Publication date:

2011

Document version

Publisher's PDF, also known as Version of record

Citation for published version (APA):

Hagen, F. N. (2011). The hieratic dockets on the cuneiform tablets from Amarna. Journal of Egyptian Archaeology, 97, 214-216. 


\title{
THE JOURNAL OF \\ Egyptian \\ Archaeology
}

\author{
VOLUME 97 \\ 2011
}

PUBLISHED BY

THE EGYPT EXPLORATION SOCIETY

3 DOUGHTY MEWS, LONDON WC1N 2PG

ISSN $0307-5133$ 
The Fournal of Egyptian Archaeology

All rights reserved

ISSN 0307-5I33

website: http://www.ees.ac.uk/publications/journal-egyptian-archaeology.html

Published annually by

The Egypt Exploration Society

3 Doughty Mews

London WC1N 2PG

Registered Charity No. 212384

A limited Company registered in England, No. 25816

Printed in Great Britain by

Commercial Colour Press Plc

Angard House, I 85 Forest Road

Hainault

Essex IG6 3HX

\section{Editorial Team}

Roland Enmarch, Editor-in-Chief

Violaine Chauvet, Editor

Mark Collier, Editor

Chris Eyre, Editor

Cary Martin, Editor

Ian Shaw, Editor

Glenn Godenho, Editorial Assistant

editorial email address: jea@ees.ac.uk 
fragments come from bases, so that there is no way to measure how large these statues were. A useful comparison can, however, be made to a piece that almost certainly came from the Great Palace. The top half of a pierced earlobe from a granite colossus $\left(\mathrm{S}-55_{23}\right)$ is preserved across its entire width of $4.4 \mathrm{~cm}$. The complete ear, if it had the tall shape of those on the Karnak colossi, would be fairly close in size to the ear on S-7I63 (lobe $4.2 \mathrm{~cm}$ wide). What little evidence survives at Amarna, where the statues were far more thoroughly demolished, suggests that at least some colossi there were similar in style to those at East Karnak.

There is no reason to assume that $\mathrm{S}-7 \mathrm{I}_{3} 3$ was carved in practice for a specific statue of exactly the same size. It could simply be a generic colossal ear. Still, it is helpful to know that it falls within the range of scales for colossi erected in royal buildings in the central city.

In sum, the presence of the scatter of hard-stone pieces along with a possible practice ear suggests that a sculptors' workshop existed on the site. Such a facility might be a continuation of the service area immediately south of the Small Aten Temple, where evidence for the creation of small objects and statuary has been found. Such a work area would perhaps parallel the workshop at the north end of the Great Palace and directly across the main road from the Great Aten Temple, excavated by Flinders Petrie in I $89 \mathrm{I}-92$ and by the EES in the I930s. ${ }^{\circ}$ Investigation of sculptors' workshops in the ancient city is ongoing and will be covered in the publication of the statuary program at Amarna, currently in progress.

Kristin Thompson

\section{The hieratic dockets on the cuneiform tablets from Amarna}

A new reading is proposed for a hieratic sign found on several cuneiform tablets at Amarna, which indicates that scribes annotated certain letters received by the administration as 'processed' $(s p \underline{h} r)$.

IN a recent article, P. Abrahami and L. Coulon discussed the hieratic notes occasionally found on the cuneiform tablets from Amarna. ${ }^{\mathrm{I}}$ They drew attention to six examples of what seems to be a single hieratic sign, written on the tablets without any further annotations (fig. I):
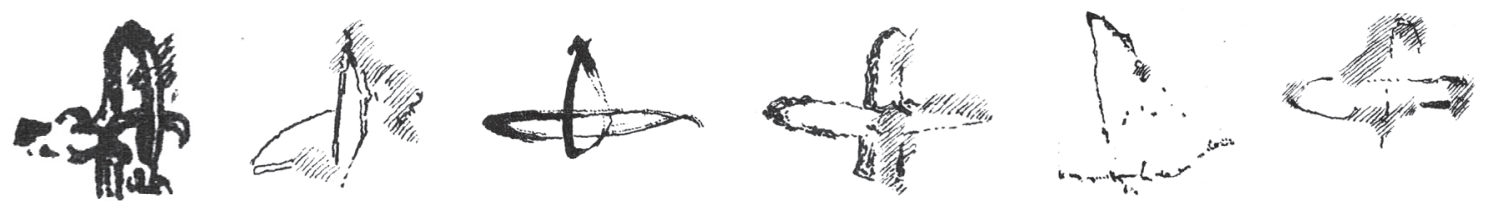

FIG. I. The hieratic annotations on EA 220, 22 I, 225, 262, 294, and 326.

Facsimiles from J. A. Knudtzon, Die El-Amarna-Tafeln (Leipzig, I 9 I 5), I, I005-7.

They proposed to read this sign 10 , following an original suggestion by A. Erman, ${ }^{2}$ and posited that 'il est raisonnable de penser que les scribes voulaient indiquer par là que la tablette avait été "communiquée» ou "traduite».3 The interpretation is not implausible but the reading of the sign is probably incorrect-there are no parallels for this usage, and even to Erman the hieratic sign looked unusual ('gross und etwas alterthümlich'). It looks more like the sign $\nRightarrow$, $s p \underline{h} r$, which often has the meaning 'copied' or 'recorded' in the

10 The place where Petrie found evidence for sculpting activity appears in square $\mathrm{P}_{39}$, sheet 4 , Kemp and Garfi, Survey of the Ancient City. The exact location of the EES workshop excavations was not recorded but was probably in the same general area.

${ }^{\text {I }}$ P. Abrahami and L. Coulon, 'De l'usage et de l'archivage des tablettes cunéiformes d'Amarna', in L. Pantalacci (ed.), La lettre d'archive: Communication administrative et personelle dans l'Antiquité proche-orientale et égyptienne (Bibliothèque générale 32; Cairo, 2008), I-26, especially I3-I 7 .

2 A. Erman, in H. Winckler, 'Verzeichniss der aus dem Funde von el-Amarna herrührenden Thontafeln', $Z \ddot{A} S$ 27 ( I 889), 63-4.

3 Abrahami and Coulon, in La lettre d'archive, I 7. 
context of state administration, where grain tax, for example, is 'recorded' by scribes. ${ }^{4}$ In fact, the specific usage as seen in the Amarna tablets — the sign $\nRightarrow$ added at some point in time after the main text was written - is paralleled in an administrative ostracon from Deir el-Medina, O. Gardiner 7 (fig. 2). ${ }^{5}$ This limestone flake has an administrative text recording some stonework carried out by workers on an unidentified building project, and is inscribed on both the front and the back. Across the text, on both sides, is a large $s p \underline{h} r$-sign, perhaps indicating that the information had been entered into an official work journal on papyrus. ${ }^{6}$
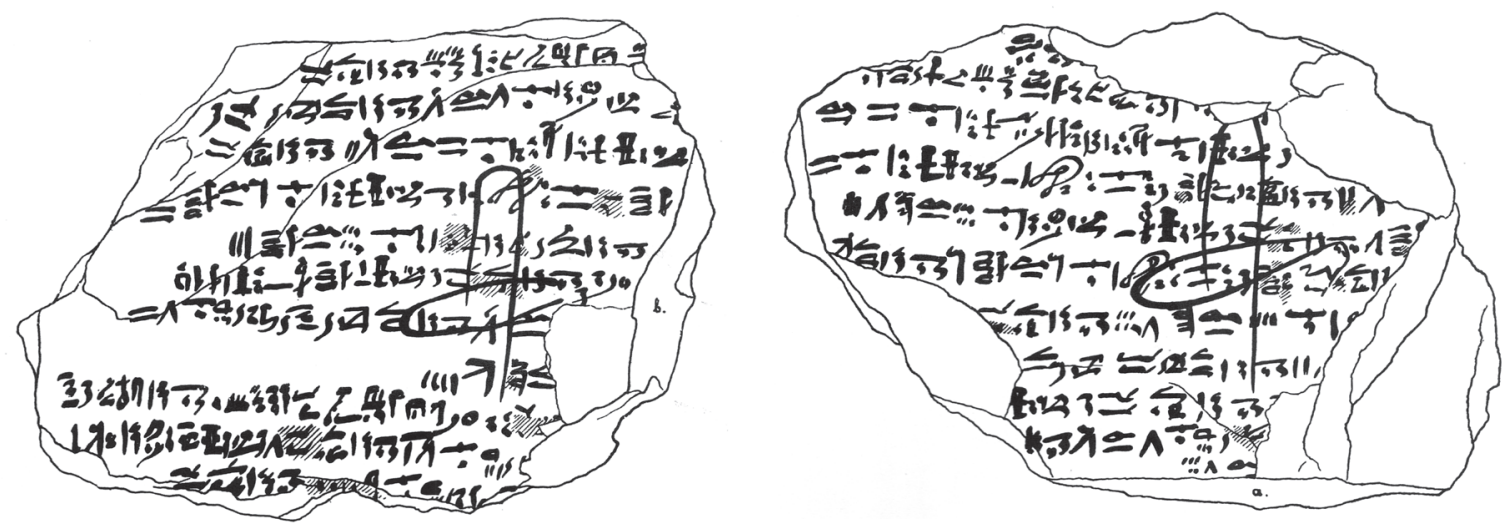

FIg. 2. O. Gardiner 7 (= O. Ashmolean Museum 7).

Facsimiles from Černý and Gardiner, Hieratic Ostraca, pl. xxiiA (courtesy of the Griffith Institute, Oxford).

I know of no other examples of this in any of the thousands of administrative ostraca from the site, so it can hardly have been a standardised practice there, but it does provide a clear example of this particular use of the sign. In the context of the Amarna tablets, the annotation could mean 'copied' or 'recorded', or even 'circulated', ${ }^{7}$ but whatever the exact nuance of the word might be, it clearly relates to the processing of the tablets by the Egyptian administration in the records office, as Abrahami and Coulon stated. Further evidence of processing of the tablets is evident in the docket of EA 27 , which reads: ${ }^{8}$

[Year] 2, month I of Peret, day [...]. One was in the Southern City in the villa $(b h n)$ of Haemakhet. Copy (mitt) of the Naharin letter which the messenger Pertja and the messenger $[\ldots]$ brought.

The existence of the docket demonstrates that the receipt of letters by the royal administration was occasionally recorded, presumably primarily when the king himself was not present at the Residence. The interpretation of the word mitt/mity, 'copy', normally used in Egyptian to indicate a copy of another text but not necessarily in the same script or language, ${ }^{9}$ is problematic, however, and has been the object of some debate. C. Kühne suggested that it referred to the surviving tablet being a Mitanni-made copy in Akkadian of an original letter

4 Wb. IV, I06.I I-ı07.6; A. H. Gardiner, 'Ramesside Texts Relating to the Taxation and Transport of Corn', FEA 27 ( I 94I), 20 with n. 2.

5 J. Černý and A. H. Gardiner, Hieratic Ostraca (Oxford, I957), 7, pl. xxiiA.

6 The recording practices of the administration of the work on the royal tombs is poorly understood, despite the abundance of material. For a discussion of the issues involved, and some tentative conclusions, see K. Donker van Heel and B. J. J. Haring, Writing in a Workmen's Village: Scribal Practice in Ramesside Deir el-Medina (EU I 6, Leiden, 2003), I-80.

7 Cf. C. J. Eyre, 'The Adoption Papyrus in Social Context', $\mathcal{F E} 778$ (1992), 208 n. 6, who suggested the meaning 'publicise' in a legal context.

${ }^{8}$ W. Fritz, 'Zum Datierungsvermerk auf der Amarnatafel Kn 27', $S A K$ i 8 (i 99 r), 2 I 2.

9 Wb. II, 39. Cf. W. Helck, 'Eine Stele des Vizekönigs W's $r$-Śt.t', $7 N E S$ I4 (1955), 22-3 I, esp. 28, for mity used to describe a monumental copy of a hieratic letter from Amenhotep II. For the term used of an Egyptian translation from Akkadian, see A. Spalinger, 'Considerations on the Hittite Treaty between Egypt and Hatti', SAK 9 (198I), 302. 
written in Hurrian, ${ }^{\mathrm{I}}$ and was followed in this by W. L. Moran, ${ }^{\mathrm{II}}$ while F. J. Giles thought that it meant the tablet found at Amarna was 'a cuneiform copy of a cuneiform original prepared for the archives', with no further indication of what the language of this original would have been. ${ }^{{ }^{2}}$ Kühne reasoned that the place of origin of the tablet must have been Mitanni based on an impressionistic analysis of the physical characteristics as well as linguistic and palaeographic aspects, ${ }^{13}$ and his conclusion was recently confirmed by petrographic analysis of the tablet which concluded that 'this tablet is undoubtedly a letter from Mitanni and not an Egyptian back-up copy'. ${ }^{14}$ The Egyptian designation 'copy', in other words, does not here refer to a locally produced cuneiform copy of an incoming letter, but rather to the manuscript's status as a written 'copy' of the message delivered orally by the Mitanni messengers named in the docket. ${ }^{15}$ Again the rarity of such dockets among the hundreds of surviving tablets from Amarna shows that this was not a standardised practice, ${ }^{16}$ and suggests that it was not part of a widespread and consistent strategy to make administrative documents accessible in an archival context. ${ }^{17}$ Given that reconstructions of the reception and processing of the Amarna letters rely to a large extent on conjecture, ${ }^{18}$ these hieratic dockets provide rare but welcome evidence of such secondary handling.

FREDRIK HAGeN

\section{A sun-shade temple of Princess Ankhesenpaaten in Memphis?}

Publication of the Amarna period block MRAH inv. 449 I, part of a sloping balustrade perhaps from a sun-shade temple of Princess Ankhesenpaaten in Memphis. The inscription is noteworthy for containing a unique instance of the re-carving of the name of Aten from form IIa to either IIb or III. There follows an excursus on the Memphite 'Horizon of Aten'.

The Memphite Amarna period block kept in the Brussels Museum (Musées Royaux d'Art et d'Histoire inv. 449I) has long been known, but no photograph of it has ever been

Io C. Kühne, Die Chronologie der internationalen Korrespondenz von El-Amarna (AOAT i 7; Neukirchen, I 973), 44 n. 209.

${ }^{\prime 1}$ W. L. Moran, The Amarna Letters (Baltimore, 2000), xvii.

${ }^{12}$ F. J. Giles, The Amarna Age: Western Asia (ACE Studies 5; Warminster, 1997), 39. Compare the comments by K. A. Kitchen, Suppiluliuma and the Amarna Pharaohs (Liverpool, I962), 7 n. I, who also assumes that the tablet is an Egyptian-produced copy of another cuneiform text.

I3 Kühne, Chronologie der internationalen Korrespondenz, 44 n. 209; cf. Fritz, SAK I 8 (I99 I), 2 I4 with n. 28.

${ }^{14}$ Y. Goren, I. Finkelstein, and N. Na'aman, Inscribed in Clay: Provenance Study of the Amarna Tablets and other Ancient Near Eastern Texts (Tel Aviv, 2004), 42.

${ }^{15}$ On the general context of delivery of messages at the Amarna court, see A. L. Oppenheim, 'A Note on the Scribes in Mesopotamia', in H. G. Güterbock and T. Jacobsen (eds), Studies in Honor of Benno Landsberger on his Seventy-fifth Birthday (Assyriological Studies I6; Chicago, I965), 254-6; M. Valloggia, Recherche sur les 'messagers' (wpwtyw) dans les sources égyptiennes profanes (HEO 6; Geneva, I 976), 275-7. The argument of S. A. Meier, The Messenger in the Ancient Semitic World (Harvard Semitic Monographs 45; Atlanta, I 988), I66-7, that such oral delivery was not necessarily verbatim, is less relevant here; the central issue is that messengers generally delivered their messages by speaking before the king.

${ }^{16}$ According to the original publication of the fragmentary hieratic docket on EA 23 by C. Bezold and E. A. W. Budge, The Tell el-Amarna Tablets in the British Museum (London, I892), xlii-xliii, pl. 23, that entry also contained the word 'copy', but J. Černý, after his re-examination of the tablet in I 964, concluded: 'There are many traces [after $p r-h$ r, 'House of Rejoicing', in line two] but they do not agree with Budge's reading', as reported by Kühne, Chronologie der internationalen Korrespondenz, 38 n. I 78 . However, digital photographs of the tablet available under 'E29793' on the British Museum website < http://www.britishmuseum.org/research/search_the_ collection_database.aspx $>$ (accessed I2 March 20I0) show clear traces of $\xi_{\forall} \%$, mit $[t]$ in line two. Petrographic analysis of this tablet demonstrated that it too originated in Mitanni, not in Egypt (Goren et al., Inscribed in Clay, 4I), proving that-like EA 27-it cannot be an Egyptian-produced copy of another cuneiform tablet.

${ }_{17}$ The issue of archival practices in pharaonic Egypt is complex: a recent introduction (with a deliberately minimalist approach to the evidence) is C. J. Eyre, 'On the Inefficiency of Bureaucracy', in P. Piacentini and C. Orsenigo (eds), Egyptian Archives (Milan, 2009), I 5-30, which to my mind downplays the potential distortion caused by the uneven survival of the sources.

18 The comments by Moran, Amarna Letters, xvii-xviii, are symptomatic; compare Giles, Amarna Age, 43-7. 